\title{
Customizing Products through Application of Group Technology: A Case Study of Furniture Manufacturing
}

\author{
Nikola Suzić* - Branislav Stevanov - Ilija Ćosić - Zoran Anišić - Nemanja Sremčev \\ University of Novi Sad, Faculty of Technical Sciences, Serbia
}

Satisfying customer needs becomes increasingly complex when a product customization element is included. This paper presents a case of transforming a manufacturing system, as a part of implementing mass customization strategy in the panel furniture manufacturing company. The need for an effective implementation of customization strategy shows that shop-floor reconfiguration is necessary in order to produce what customer wants at a low cost and on time. One way of achieving this is to implement group technology approach, by creating product and machine groups and simplifying material flows. The aim of the presented study is to show an application of production flow analysis in the process of converting the mass production company to a mass customization system. The paper presents benefits of synergy created by using group technology and production flow analysis in enabling mass customized production.

Keywords: mass customization, group technology, production flow analysis

\section{INTRODUCTION}

With an increased range of products offered on the global market, customers have an opportunity to choose what they want and even creating and designing their own products. Once exclusivity, offered only to buyers of luxury products, product customization today comes to a wider range of customers with an approach known as mass customization. Customer participation in product realization is becoming essential for market success [1]. Dealing with new market trends and an emergence of "markets of one" [2], production companies today must take mass customization into account in order to stay competitive. In order to organize production system to be suitable for the implementation of mass customization strategy, a company should consider issues related to optimizing the way the products are created.

The research conducted in this paper represents an effort towards successful implementation of mass customization strategy into the furniture industry company. The introduction of the mass customization strategy into the production system is based on successfully dealing with technical capabilities of the company on one hand and the needs and wishes of customers on the other. In order to achieve this goal, the application of group technology (GT) and production flow analysis (PFA) has been proposed. The group technology appliance offers better control of the production process and is applied towards achieving optimal use of capacities and flexibility of the production system [3].

The first part of the paper brings the literature overview of mass customization and production flow analysis approach. The second part of the paper shows the case study of the furniture company and implementation of mass customization in practice. Conclusions provide advantages of proposed system organization.

\section{LITERATURE OVERVIEW}

\subsection{The Mass Customization Concept}

Mass customization (MC) is a relatively new paradigm based on the production of customized products with mass production efficiency [2]. Emerged in late 20th century the paradigm is today more relevant than ever. Companies which embraced this strategy in sales and production added a new value to their business [4]. This has proven as a good strategy for some small and medium enterprises (SME's) [5] as well as for big multinational companies (Dell, Nike, Adidas, etc.) [6]. Nevertheless, implementation of mass customization strategy still presents a challenge for companies and dealing with the new combination of company resources is seen as crucial by many authors [7]. Although a number of companies proved that implementation of mass customization is possible, there is still a question of combination of factors that lead to the success of one but failure of another on the MC market.

Mass customizers are today able to customize products quickly for individual customers or for niche markets, in some cases responding to customer orders at greater speeds than a mass producer can. Using the same principles, mass customizers can Build-to-Order both customized products and standard products without forecasts, inventory, or purchasing delays.

The critical moments in mass customized production are product variety, product prices and 
period of the product delivery. These are factors relevant to the solution space mentioned by Piller and Tseng [8], which is to be determined by the production company. The variety of customized production is based on product families, modular or scaled, and product platforms, created either with top-down or bottom-up approach [9].

MC production is supported by configuration tools, either online (external) or offline (internal) [10]. The configuration tools enable the full capacity of mass customization and with usage of a good customer database can lead to enhanced customer loyalty [9]. In the work of Fain et al. [11] the important role of the user in product development is emphasized. Furthermore, dealing with an optimal number of product variants becomes an important task of design process in production company [12].

The mass customized production is in practice realized with flexible production systems [13] able to deal with a variety of manufactured parts and adjustable assembly operations. In order to embrace mass customization production companies must determine the depth of the customization [14] which is suitable for company's level of technology. In order to be successful in MC production a company must be successful in designing products, the marketing of products, create a functional configuration process and configuration tool, but first of all it should have a production configured in a way that can support the needs for product variety and individual orders.

\subsection{Group Technology}

Group technology is an approach to production system organization which has existed for many decades.
Group technology first appeared in the book of Mitrofanov [15]. GT is based on the idea of grouping parts by using similarity. The approach results with cellular organization of machines in production systems [16] and [17]. This approach gave many benefits to solving problems like long lead times, large setup times, increased Work-In-Progress inventories, large inventories of finished goods, poor part quality and high unit costs, as shown in Wemmerlöv and Hyer [18] and in Wemmerlöv and Johnson [19].

Grouping of parts can be achieved in several ways, firstly through finding similarities in part geometry by using classification and coding system $(\mathrm{C} \& \mathrm{C})$, but this method is not always the most suitable. Burbidge [20] indicates several reasons which make the use of classification and coding system unsatisfactory. Such reasons lie in the facts that C\&C system does not group machines, it also tends to group parts made of different materials and size, and is time consuming and complex. Grouping of parts can also be done by using part drawings which is known as the visual inspection method. This method is hardly practical as the part number grows. Another way of part group creation is by finding same processing technology steps that are shared by parts. Parts that have the same technological operations can be grouped together. This method is known as PFA which has been developed by John. L. Burbidge [21] and [22]. PFA consists of several phases which include an analysis of material flow in the production system, forming part families and machine groups, analysis of material flows within cells and analysis of tools concerning the setup time reduction criteria. Several cases indicate the benefits of implementation of PFA and can be found in Wemmerlöv and Johnson [19] and [23], in Lee et al.

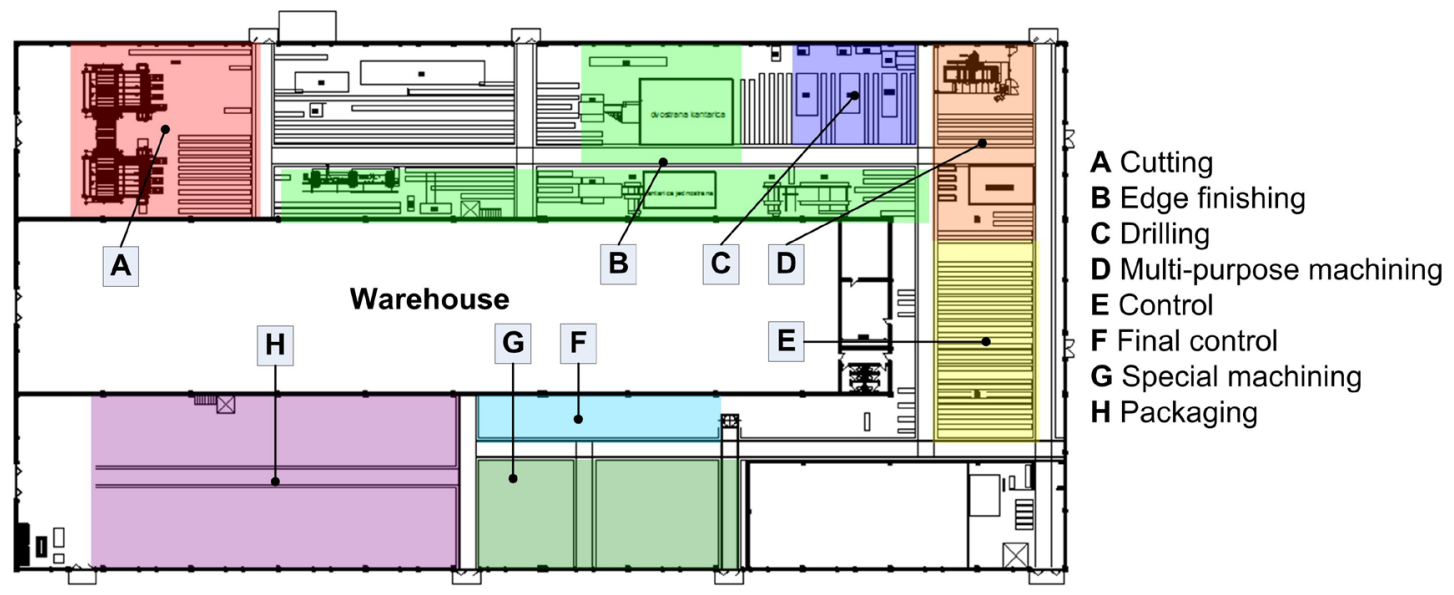

Fig. 1. Shop-floor process layout 
[24], in Ribeiro and de Araújo [25] and Hameri [26]. PFA has proven itself as a simple and efficient method to achieve cellular manufacturing organization.

\section{CASE STUDY OF FURNITURE MANUFACTURING}

\subsection{Shop-Floor}

For the purposes of research a furniture production company was chosen. The chosen company produces panel furniture on mass production scale. Company produces 440 different products, such as wardrobes, beds, kitchen cabinets and all kinds of smaller pieces of furniture for the household. Shop-floor process layout with transport routes is given in Fig. 1.

Production starts with the cutting of basic shapes of wood panels for future product parts. The cutting operation consists of two cutting machines. The next phase of production is edge finishing which contains three distinctive machines for edge finishing. All three machines have different production and technology capabilities. Next, parts go to the drilling operation which contains three machines. Further into the process, two CNC centers are used for complex shapes of parts. The production process is finalized with visual control of parts, final control and packaging. Special machining is done on some parts where special features, such as mirrors for an example, are assembled on them.

\subsection{Market Research}

In order to determine the percents of customers who want customized products, market research is conducted. The goal of the research was to reveal the potentials of furniture market in the province in Serbia. For the purposes of the research a questionnaire was composed. Main subjects of the research included:

- Location of participants (showing geographical area in percents).

- Profile of participants (by gender, age, place of living and size of settlement).

- Preferences of furniture buyers (whether they plan to buy small or large pieces of panel or stylish furniture, or both kinds equally).

- Experiences with previous purchase of furniture (where do buyers most frequently go to buy the furniture, and how often does it happen that the offer of standard furniture does not match their needs).

- Properties of standard furniture offer that customers marked as inadequate (by color, dimensions, quality and functionality).
- Significance of customization to customers (whether they would like to have the option to customize their furniture during next purchase).

- Readiness of paying more and waiting longer for customized furniture.

- Internet usage and readiness to use the web in order to customize furniture.

The research has shown that:

- The given market is oriented on panel furniture (63\%).

- Furniture stores are the place where most buyers purchase their furniture (67\%). If the buyer would not find what they were looking for they would go to a craftsman (carpenter). Only every tenth buyer goes directly to a carpenter.

- Dimensions (40\%) and functional characteristics $(48 \%)$ of furniture are the main properties with which customers were not satisfied in their past purchases. Mass customization can meet these needs very successfully.

- Majority of buyers $(60 \%)$ would like to have the opportunity to change properties of furniture, and $33.3 \%$ more would like to have that option even if it would not mean a lot to them.

- The population of internet users in the region is satisfying $(82 \%)$, and furthermore most of them $(70.7 \%)$ would be ready to customize their furniture over the Internet.

The research has shown that there is a group of potential buyers of customized furniture ready to pay more and wait longer just to get a product that better fits their needs. Research has also shown that customer needs are not always met with standard panel furniture offer.

The need to embrace and implement mass customization has been recognized by company management. The first step in this process was to find a way to organize production system in a way which can support customization.

\subsection{System Analysis}

The analysis of the system was done through several steps which consist of analysis of product assortment, machine line-up, material flow, as well as the technological capabilities of the machines.

This company is not a complex system in terms of PFA, so the company flow analysis was not necessary. The analysis started with factory flow analysis (FFA).

The whole product assortment of 440 products was analyzed part by part. Every product and product part needs to be compared with similar products and parts from the production assortment. Similarities 
can be found in the attributes of material (such as thickness and color for example), the quality of material and compatibility of parts embedded into multiple products.

The product assortment was analyzed manually by using product explosion and parts material flow (production technology specifications). The production program is wide, but is mostly made up of parts that have similar processing. Fig. 2 shows a chosen example of five products from product assortment: the horizontal dresser, the wardrobe, the shelves, the vertical dresser and the computer table.

The whole product assortment is produced on a number of machines shown in Table 1.

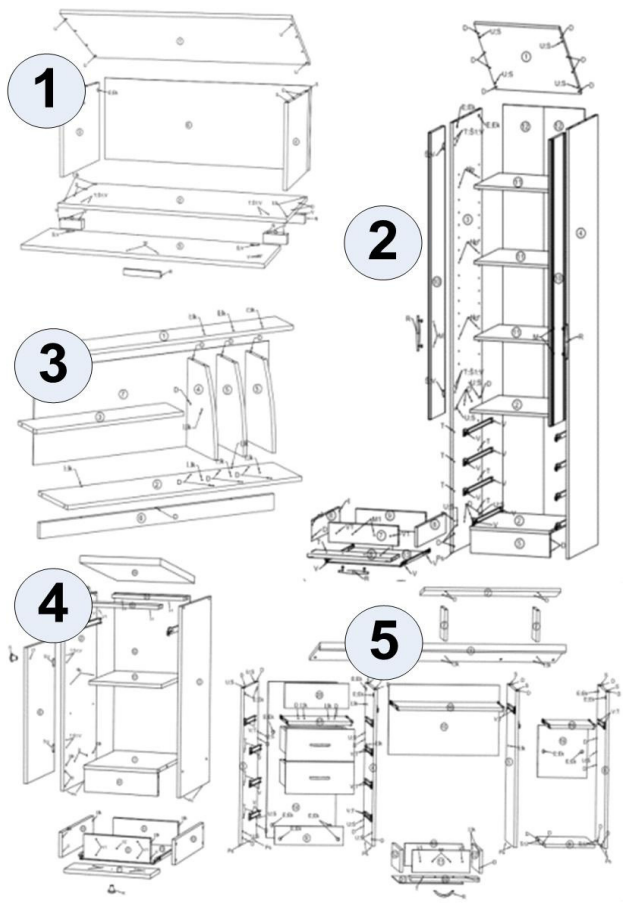

Fig. 2. The example of the product assortment part analysis

\subsection{Creation of Product Part Groups}

Based on production technology, available machines and analysis of product parts the part groups were created. During the creation of the part groups, several things were taken into account, like the work operations that are needed to be performed on the machines, the efficiency of the machines and the sizes of the parts which are produced. The parts which, at a first glance, have very similar (almost identical) production technology specifications are classified into different groups because of their size (small, medium and big). All the parts are made of plywood, which can have different thickness. Decomposing of 440 products led to the creation of 16 distinct part groups shown in Fig. 3, red represents processing done on each part group. The production process of the part groups, according to the routing can be seen in Table 2.

Table 1. The machine list

\begin{tabular}{cl}
\hline $\begin{array}{c}\text { Machine } \\
\text { number }\end{array}$ & Machine name \\
\hline 1 & Cutting machine \\
\hline 2 & One side edging machine \\
\hline 3 & Two side edging machine with gutter making option \\
\hline 4 & Two side edging machine \\
\hline 5 & Two side edging machine \\
\hline 6 & Drilling machine \\
\hline 7 & Drilling machine \\
\hline 8 & Drilling machine \\
\hline 9 & Multi-purpose machining center (drilling, cutting and \\
\hline 10 & Drimming) \\
\hline $11^{*}$ & Visual control of parts and manual finishing \\
\hline $12^{*}$ & Final control of products \\
\hline $13^{*}+$ & Special machining \\
\hline $14^{*}$ & Packaging \\
\hline * The numbers 11, 12, 13 and 14 represent the part operations done \\
$\begin{array}{c}\text { after the processing. } \\
+ \text { Special machining is done on some of the product parts (parts with } \\
\text { mirrors, printing, etc.). }\end{array}$
\end{tabular}
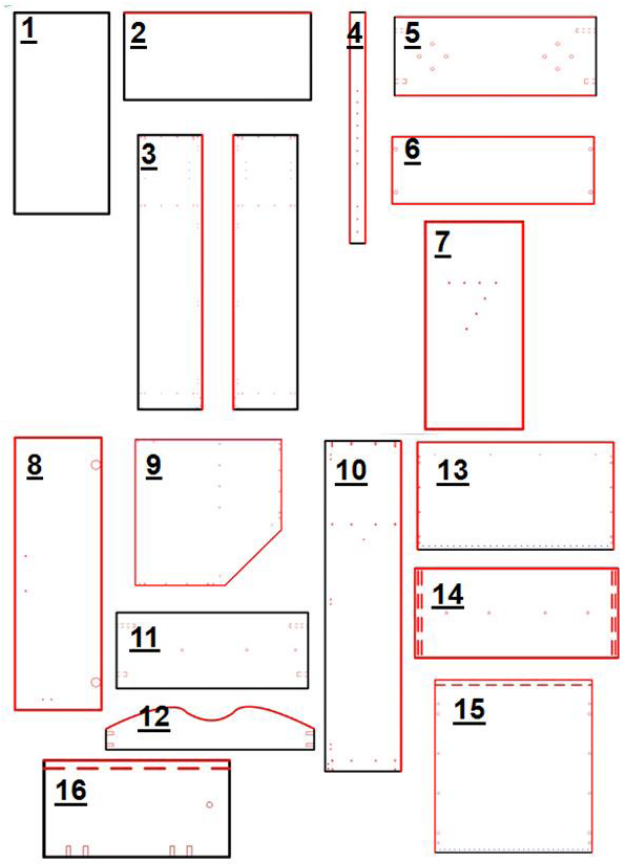

Fig. 3. Derived part groups 
Table 2. Routing of part groups

\begin{tabular}{cc}
\hline Part group & Technology sequence $^{*}$ \\
\hline 1 & 1 \\
\hline 2 & $1-3$ \\
\hline 3 & $1-3-6$ \\
\hline 4 & $1-4-6$ \\
\hline 5 & $1-5-6$ \\
\hline 6 & $1-5-7$ \\
\hline 7 & $1-4-6$ \\
\hline 8 & $1-4-10$ \\
\hline 9 & $1-3-9$ \\
\hline 10 & $1-3-6$ \\
\hline 11 & $1-8$ \\
\hline 12 & $1-9$ \\
\hline 13 & $1-3-4-6$ \\
\hline 14 & $1-2-4-6$ \\
\hline 15 & $1-2-4-6$ \\
\hline 16 & $1-2-6$ \\
\hline
\end{tabular}

*The technology numbers correspond to the previously given machine list in Table 1.

Obtained part groups as well as their routing and available machines in the system led to the creation of material flow diagram for part groups Fig. 4.

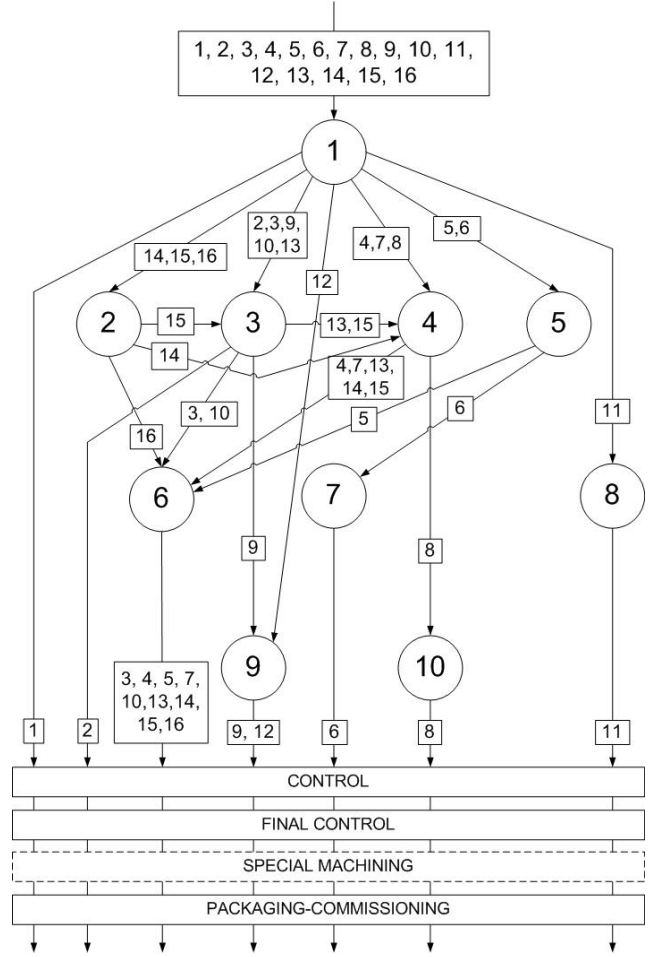

Fig. 4. Material flow diagram for part groups

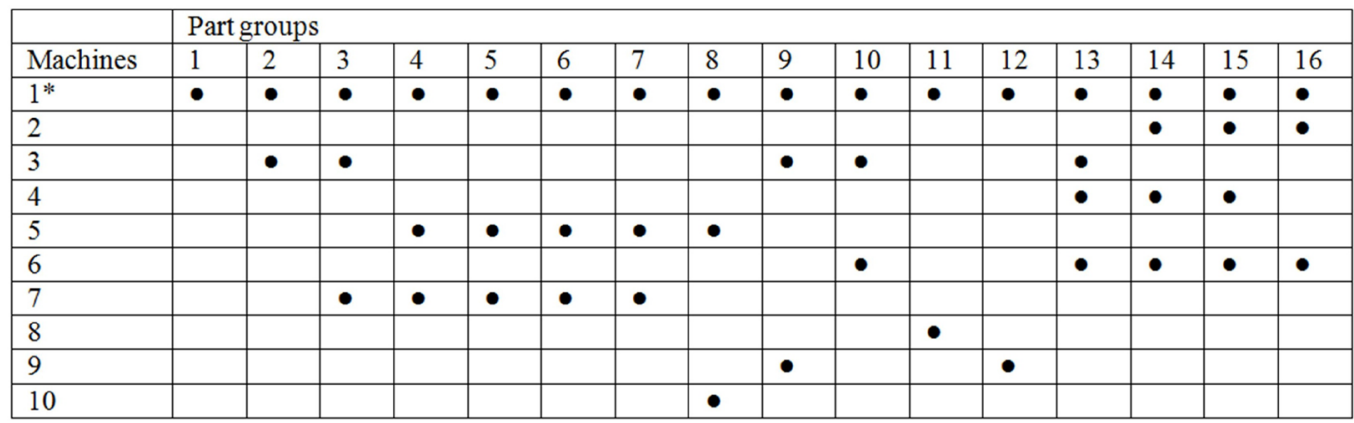

*There are two cutting machines in the production system. In the next matrix they will be presented separately as $1 \mathrm{a}$ and $1 \mathrm{~b}$ cutting machines.

Fig. 5. The starting matrix

\begin{tabular}{|c|c|c|c|c|c|c|c|c|c|c|c|c|c|c|c|c|}
\hline & Par & grou & & & & & & & & & & & & & & \\
\hline Machines & 14 & 15 & 16 & 13 & 2 & 3 & 9 & 10 & 12 & 4 & 5 & 6 & 7 & 8 & 11 & 1 \\
\hline $1 \mathrm{a}$ & $\bullet$ & $\bullet$ & $\bullet$ & $\bullet$ & $\bullet$ & $\bullet$ & $\bullet$ & $\bullet$ & - & & & & & & & \\
\hline 2 & $\bullet$ & $\bullet$ & $\bullet$ & & & & & & & & & & & & & \\
\hline 3 & & & & $\bullet$ & - & $\bullet$ & - & $\bullet$ & & & & & & & & \\
\hline 4 & $\bullet$ & $\bullet$ & & $\bullet$ & & & & & & & & & & & & \\
\hline 6 & $\bullet$ & $\bullet$ & $\bullet$ & $\bullet$ & & $\bullet$ & & $\bullet$ & & & & & & & & \\
\hline 9 & & & & & & & $\bullet$ & & - & & & & & & & \\
\hline $1 \mathrm{~b}$ & & & & & & & & & & $\bullet$ & $\bullet$ & $\bullet$ & $\bullet$ & $\bullet$ & $\bullet$ & - \\
\hline 5 & & & & & & & & & & $\bullet$ & $\bullet$ & $\bullet$ & $\bullet$ & $\bullet$ & & \\
\hline 7 & & & & & & & & & G2 & $\bullet$ & $\bullet$ & $\bullet$ & $\bullet$ & & & \\
\hline 8 & & & & & & & & & & & & & & & - & \\
\hline 10 & & & & & & & & & & & & & & $\bullet$ & & \\
\hline
\end{tabular}

Fig. 6. Resulting incidence matrix - Division into machine groups 


\subsection{Incidence Matrix (Clustering Analysis)}

According to PFA methodology, the starting matrix with machines and part groups is given in Fig. 5.

\subsection{Cell Formation}

In this initial setting part groups are assigned to machines according to routing criteria. However, some machines are capable of processing other part groups, for example all drilling machines are able to process all of the required parts. This means that the rotation of machines is a possible option for cell formation. In Fig. 6 the resulting incidence matrix is given. It shows that two cells can be formed with no exceptions in the cell formation.

In the process of cell formation some machines were replaced by equivalent machines capable of processing the given part groups. The replacement is done in groups 4,7 and 8 which are moved from machine number 4 to machine number 5 . Also, part groups number 4, 5 and 7 are moved from machine number 6 to machine number 7. Replacement from one machine to another was done with the intention of creating unraveled material flows, thus enabling the creation of the separate material flows and manufacturing cells. The replacement was done without a significant impact on machining time and machine efficiency since the characteristics of drilling machines are comparable and plywood parts are done with similar technology. On the other hand, the intention was to create notable savings in lead times with cellular organization. Lead times of parts are not affected with the machine changes since they will not considerably differ. On the other hand, lead times are impacted greatly by a significant decrease of unfinished production and queues brought by new production organization. This way, the forming of two distinct manufacturing cells is enabled (one cell for complex parts and the other one for less complex parts). Cells are created with no additional costs. Material flow diagram for these two cells is shown in Fig. 7.

The FROM/TO matrices for two cells are shown in Fig. 8. The matrices show that there are no returning flows in the production system organized this way.

Tooling analysis (TA) as the part of PFA was not conducted because of the nature of manufacturing technology. In the panel furniture industry tools have a high level of standardization and unification; for example, drills used for shelf positioning are equal for all the products that company makes. All tool types are treated in this way, so there was no need for tool scheduling in the cells.

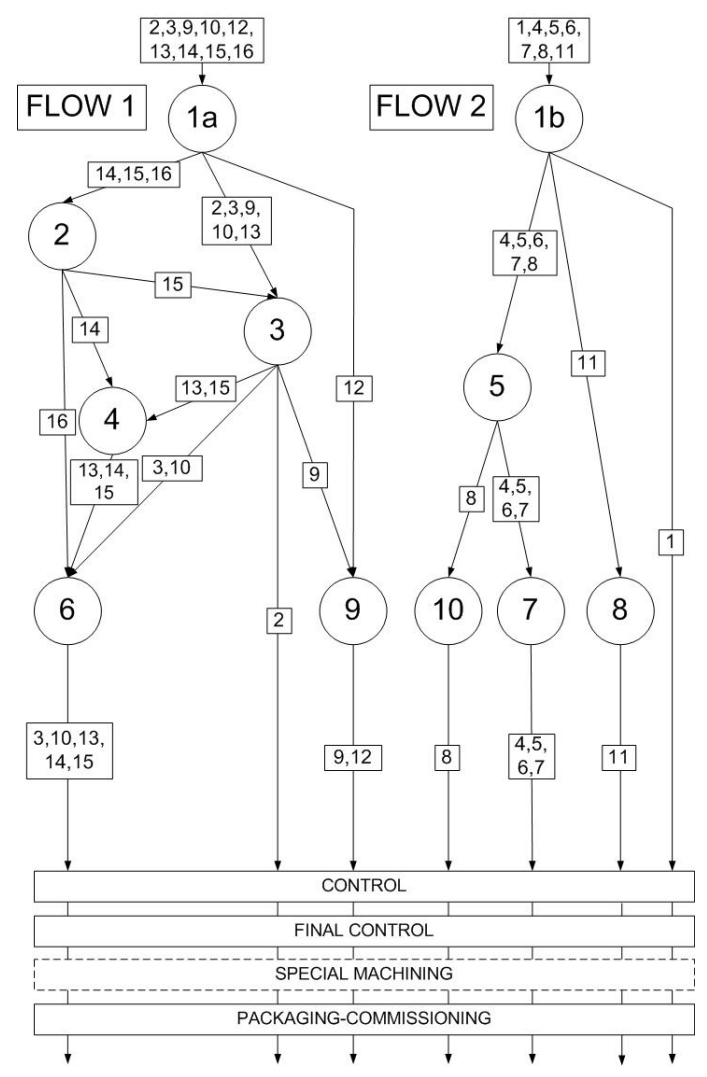

Fig. 7. Material flow diagram for cells

a)

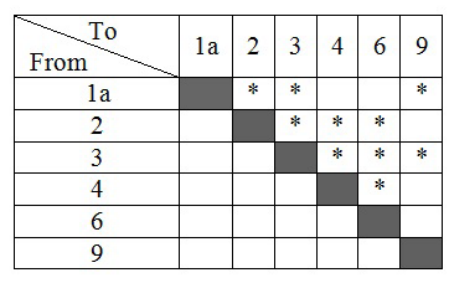

b)

\begin{tabular}{|c|c|c|c|c|c|}
\hline From & $1 \mathrm{~b}$ & 5 & 7 & 8 & 10 \\
\hline $1 \mathrm{~b}$ & & $*$ & & $*$ & \\
\hline 5 & & & $*$ & & $*$ \\
\hline 7 & & & & & \\
\hline 8 & & & & & \\
\hline 10 & & & & & \\
\hline
\end{tabular}

Fig. 8. FROM/TO matrices of manufacturing cells;

a) for manufacturing cell 1, b) for manufacturing cell 2

\section{CONCLUSIONS}

Mass customization production environment has evolved over the past two decades. It has developed in theory and as an industrial practice. In this paper, the presented research, theoretical as well as 


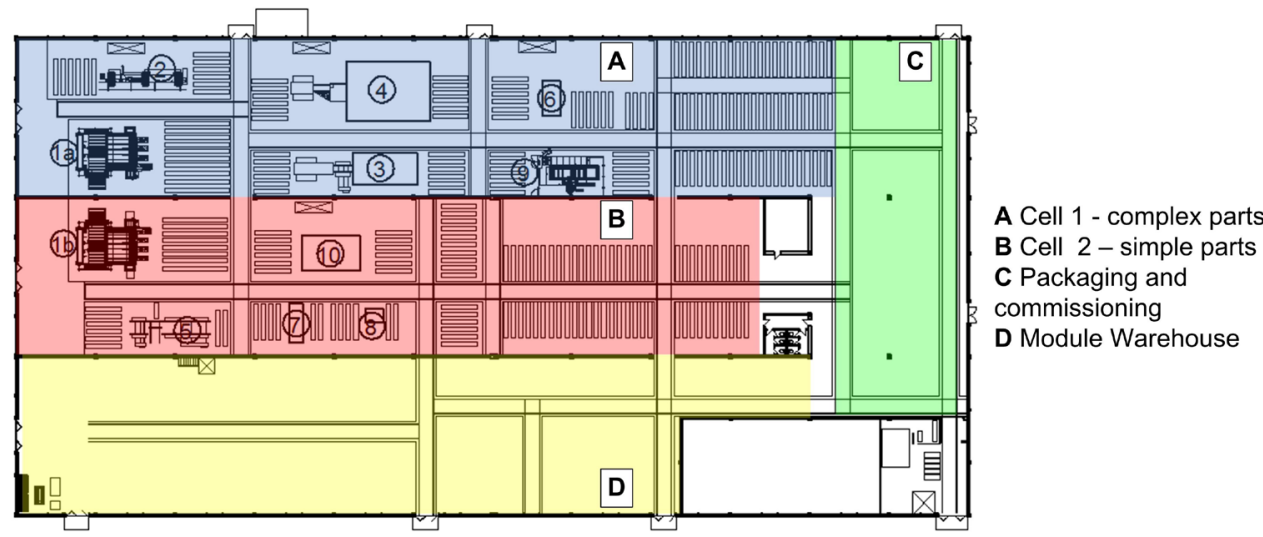

Fig. 9. Reconfiguration of shop-floor

that conducted in the industry, showed that mass customization is possible to achieve by implementing GT philosophy.

Implementation of GT principles through analysis of the system has led to a new layout presented in Fig. 9. Shop-floor has been divided into three work units:

- Manufacturing cell 1 - for production of complex parts.

- Manufacturing cell 2 - for production of simple parts.

- Area for packaging and commissioning of modules.

This lead to increased effects in the sense of:

- decreasing the set-up times (a decrease from 3 up to 10 times, depending on the machine),

- $\quad$ simplifying the material flows in the system,

- simplifying the launch of orders into the system,

- $\quad$ shortening the lead times in the system (from 8 up to 12 times depending on the concrete part),

- $\quad$ shortening transport ways and with it the transport times in the system (approx. twice),

- decreasing the size of unfinished production and queues between the operations significantly.

However, full transformation from mass production to mass customization system cannot only rely on GT and does not end with shop floor transformation. Manufacturing cells are only the first step, and they enable better organization of production system. Having that in mind, in conclusion we propose the development of several systems (mainly software oriented) for mass customization:

- web enabled product configuration tool, so that customers can configure its products in the meaning of choosing the material, customizing design and choosing special features,

- $\quad$ implementation of ERP and PDM/PLM systems for an easier understanding of customer needs, product and process data management, information sharing and collaboration, analyses and corrective measures [27],

- the development of software solution for part groups creation and scheduling in a customized production environment,

- RFID part tagging, so that every part can be tracked throughout its "life" in a shop floor, and in the warehouse,

- different manufacturing process execution scenarios simulation [29] and [30], for the prediction of possible problems and the evaluation of solutions,

- integration of previously mentioned tools and systems through heavy use of XML data representation, a similar solution can be found in the work of Šormaz et al. [28].

\section{REFERENCES}

[1] Rihar, L., Kušar, J., Duhovnik, J., Starbek, M. (2010). Teamwork as a precondition for simultaneous product realization. Concurrent Engineering: Research and Applications, vol. 18, no. 4, p. 261-273.

[2] Davis, S.M. (1987). Future Perfect, Addison-Wesley Publishing Company, New York.

[3] Morača, S., Hadžistević, M., Drstvenšek, I., Radaković, N. (2010). Application of group technology in complex cluster type organizational systems, Strojniški vestnik Journal of Mechanical Engineering, vol. 56, no. 10, p. 663-675

[4] Gilmore, J.H., Pine, J.B. (1997). The Four Faces: Customization, Harvard Business Review, no. 75, p. 91101

[5] Piller, F. (2004). Mass customization: Reflections on the state of the concept. The International Journal of Flexible Manufacturing Systems, vol. 16, no. 4, p. 313-334, DOI:10.1007/s10696-005-5170-x. 
[6] Salvador, F., De Holan, P.M., Piller, F. (2009). Cracking the code of mass customization. MIT Sloan Management Review, vol. 50, no. 3, p. 71-78.

[7] Borocki, J., Ćosić, I., Lalić, B., Maksimović, R. (2011). Analysis of company development factors in manufacturing and service company: a strategic approach. Strojniški vestnik - Journal of Mechanical Engineering, vol. 57, no. 1, p. 55-68, DOI:10.5545/svjme.2010.030.

[8] Piller, F.T., Tseng, M. (2003). The Customer Centric Enterprise: Advances in Mass Customization and Personalization, Springer, New York/Berlin.

[9] Simpson, T.W., Maier, J.R.A, Mistree, F. (2001). Product platform design: Method and aplication. Research in Engineering Design, vol. 13, p. 2-22, DOI:10.1007/ s001630100002.

[10] Blecker, T., Abdelkafi, N., Kreuter, G., Friedrich, G. (2004). Product configuration systems: state-of-theart, conceptualization and extensions. 8th $^{\text {th }}$ Maghrebian Conference on Software Engineering and Artificial Intelligence, vol. 2, p. 25-36.

[11] Fain, N., Moes, N., Duhovnik, J. (2010). The role of the user and the society in new product development. Strojniški vestnik - Journal of Mechanical Engineering, vol. 56, no. 7-8, p. 521-530.

[12] Anišić, Z., Krsmanović, C. (2008). Assembly initiated production as a prerequisite for mass customization and effective manufacturing. Strojniški vestnik - Journal of Mechanical Engineering, vol. 54, no. 9, p. 607-618.

[13] Koren, Y. (2010). The Global Manufacturing Revolution-Product-Process-Business Integration and Reconfigurable Systems, John Wiley \& Sons, Hoboken, DOI:10.1002/9780470618813.

[14] Lampel, J., Mintzberg, H. (1996). Customizing Customization. Sloan Management Review, vol. 38, no. 1, p. 21-30.

[15] Mitrofanov, S.P. (1966). Scientific Principles of Group Technology, (english translation), National Library for Science and Technology, Washington, DC (originally published in 1959).

[16] Zelenović, D., Burbidge, L.J., Ćosić, I., Maksimović, R. (1995). The division of large complex production systems, into independent, autonomous units. Proceeding of $13^{\text {th }}$ International Conference of Production Research, ICPR, Global Frontiers in Manufacturing, Jerusalem, p. 213215.

[17] Zelenović, D., Ćosić, I., Maksimović, R. (1998). Design and reengineering of production systems: Yugoslavian (IISE) approaches. Monograph Group Technology and Cellular Manufacturing - State of-The-Art Synthesis of Research and Practice, Kluwer Academic Publishers, vol. 16, p. 517-537, New York.
[18] Wemmerlöv, U., Hyer, N.L. (1989). Cellular manufacturing in the U.S. industry: A survey of users. International Journal of Production Research, vol. 27, no. 7, p. 1511-1530, DOI:10.1080/00207548908942637.

[19] Wemmerlöv, U., Johnson, D.J. (1997). Cellular manufacturing at 46 user plants: implementation experiences and performance improvements. International Journal of Production Research, vol. 35, no. 1, p. 29-49, DOI:10.1080/002075497195966.

[20] Burbidge, J.L. (1989). Production Flow Analysis for Planning Group Technology. Oxford University Press, Oxford.

[21] Burbidge, J.L. (1961). The new approach to production. Production Engineer, vol. 40, no. 12, p. 769-793, DOI:10.1049/tpe.1961.0104.

[22] Burbidge, J.L. (1963). Production flow analysis. Production Engineer, vol. 42, no. 12, p. 742-752, DOI:10.1049/tpe.1963.0114.

[23] Wemmerlöv, U., Johnson, D.J. (2000). Empirical findings on manufacturing cell design. International Journal of Production Research, vol. 38, no. 3, p. 481-507, DOI:10.1080/002075400189275.

[24] Lee, H.L., Padmanabhan, V., Whang, S. (1997). Information distortion in supply chain: the bullwhip effect. Management science, vol. 43, no. 4, p. 546-558, DOI:10.1287/mnsc.43.4.546.

[25] Dos Santos, N.R., De Araújo Jr., L.O. (2003). Computational system for group technology - PFA case study. Integrated Manufacturing Systems, vol. 14, no. 2, p. 138-152, DOI:10.1108/09576060310459438.

[26] Hameri, A.-P. (2011). Production flow analysis - cases from manufacturing and service industry. International Journal of Production Economics, vol. 129, no. 2, p. 233 241, DOI:10.1016/j.ijpe.2010.10.015.

[27] Kušar, J., Rihar, L., Duhovnik, J., Starbek, M. (2008). Project management of product development. Strojniški vestnik - Journal of Mechanical Engineering, vol. 54, no. 9, p. 588-606.

[28] Šormaz, D.N., Arumugam, J., Harihara, R.S., Patel, C., Neerukonda, N. (2010). Integration of product design, process planning, scheduling, and FMS control using XML data representation. Robotics and Computer-Integrated Manufacturing, vol. 26, no. 6, p. 583-595, DOI:10.1016/j. rcim.2010.07.014

[29] Reddy, B.S.P., Rao, C.S.P. (2011). Flexible manufacturing systems modelling and performance evaluation using AutoMod. International Journal of Simulation Modelling, vol. 10, no. 2, p. 78-90, DOI:10.2507/IJSIMM10(2)3.176.

[30] Lokesh, K., Jain, P. K. (2010). Concurrently part-machine groups formation with important production data. International Journal of Simulation Modelling, vol. 9, no. 1, p. 5-16, DOI:10.2507/IJSIMM09(1)1.133. 